\title{
Relationship Finance, Informed Liquidity, and Monetary Policy
}

\author{
Luis Araujo* \\ Michigan State University and \\ Sao Paulo School of Economics-FGV \\ Pierluigi Murro \\ Luiss University
}

\begin{abstract}
We study the aggregate effects of credit relationships in an economy where lenders' effort in acquiring knowledge about firms' investments endogenously depends on their financial involvement in investments. Firms trade off the benefits of precautionary internal liquidity with the need to incentivize lenders' effort through their involvement in investment financing. We find that, through these intensive margin effects, tight credit relationships can induce suboptimally high investment levels, calling for a positive interest rate policy that departs from the Friedman rule. Loose credit relationships, however, amplify the aggregate impact of negative real shocks. Credit policies that inject liquidity into the lending sector enhance the welfare effect of credit relationships but have ambiguous effects on stabilization.
\end{abstract}

JEL Codes: D02; E02; E44; G21

Keywords: Liquidity; Credit relationships; Monetary policy

\footnotetext{
${ }^{*}$ Corresponding author. Email: araujolu@msu.edu . Address: MSU Department of Economics, Marshall-Adams Hall, 486 W Circle Dr. Rm 110, East Lansing, MI 48824. We wish to thank several seminar and conference participants at Banque de France, Federal Reserve Bank of Chicago, Luiss University, Michigan State University, Monash University, OFCE Sciences Po, University of Exeter, University of Kentucky, University of Melbourne, University of Rome Tor Vergata, SAET Conference, Santiago Finance Conference (Santiago), Workshop on Advances in Macroeconomics (Nice), for helpful comments and conversations. All remaining errors are ours.
} 


\title{
Relationship Finance, Informed Liquidity, and Monetary Policy
}

\begin{abstract}
We study the aggregate effects of credit relationships in an economy where lenders' effort in acquiring knowledge about firms' investments endogenously depends on their financial involvement in investments. Firms trade off the benefits of precautionary internal liquidity with the need to incentivize lenders' effort through their involvement in investment financing. We find that, through these intensive margin effects, tight credit relationships can induce suboptimally high investment levels, calling for a positive interest rate policy that departs from the Friedman rule. Loose credit relationships, however, amplify the aggregate impact of negative real shocks. Credit policies that inject liquidity into the lending sector enhance the welfare effect of credit relationships but have ambiguous effects on stabilization.
\end{abstract}

JEL Codes: D02; E02; E44; G21

Keywords: Liquidity; Credit relationships; Monetary policy

\section{Introduction}

The relationship between the financial sector and the corporate sector has undergone profound transformations in recent decades. Various phenomena have been indicated as sources of a dilution of credit relationships and of a trend towards more "arm'slength" financial systems. ${ }^{1}$ On the supply side, credit relationships have been challenged by mounting competition among financial institutions and from the capital market and by increasing geographical distance between banks and firms (Boot and

\footnotetext{
${ }^{1}$ Arm's length transactions are pure funding transactions. Unlike in credit relationships, the financiers perform limited or no information gathering about borrowers' assets and activities.
} 
Thakor, 2000; Krozner, 2015; IMF, 2006). Further, the growing ability of financial institutions to securitize and resell loans has allegedly diluted their incentive to engage in information-intensive credit relationships with firms (Wang and Xia, 2014; Berndt and Gupta, 2009). On the demand side, firms' increasing tendency to accumulate large cash holdings has reduced their dependence on financial institutions for day-to-day liquidity provision, possibly attenuating the intensity of credit relationships (Bates, Kahle and Stulz, 2009; Pinkowitz, 2001).

While these phenomena have been extensively documented, we still have limited theoretical understanding of how credit relationships can affect the role of the credit sector in aggregate economic activity. Does the relationship structure of the credit sector influence the equilibrium allocation and its welfare properties? Is a relationshiporiented credit sector an attenuator or an amplifier of shocks? How does the intensity of credit relationships shape the effects of monetary and credit policies? Figure 1, for example, shows how the intensity of credit relationships correlates with the patterns of economic activity in the local credit markets (provinces) of Italy, a country where firm-bank credit relationships are pervasive (Degryse, Kim and Ongena, 2009). The figure is drawn using granular data on about 40,000 firm-year observations for the 1995-2003 period. ${ }^{2}$ Though suggestive, an intriguing trade-off emerges: local markets with more intense credit relationships exhibit lower output levels (left panel) but also lower output volatility (right panel). Clearly, studying the aggregate effects of credit relationships can not only advance our understanding of the role of the credit sector in the economy at large but also yield insights for financial reforms. In the aftermath of the Great Recession, scholars and policy-makers debate whether the observed trend should be promoted or whether efforts should be made to preserve more relationshiporiented financial systems (IMF, 2006, 2012; ECB, 2014).

This paper takes a step towards examining these issues. To investigate the above phenomena, we build an economy with credit relationships and liquidity constraints. The model economy borrows elements from a broad literature in which trading frictions endogenously motivate a need for liquidity (see Lagos, Rocheteau and Wright, 2017, for a review). In our setting, we aim at capturing the central role of information-intensive credit relationships in the credit market. We then let lenders not only intermedi-

\footnotetext{
${ }^{2}$ The local intensity of credit relationships is measured with the share of firms in the province having a close-by main bank. The volatility of local (provincial) GDP is measured with the standard deviation of the GDP. More details on the data are in Section 5.3.
} 
ate liquidity but also engage in information-intensive relationships with firms. In the economy, firms obtain liquidity borrowing from lenders or holding internal liquidity (cash). Liquidity is essential for firms because the capital assets of their distressed projects need to be restructured in a decentralized asset market with search frictions. We model credit relationships following Diamond and Rajan (2000, 2001a, 2001b) and an extensive financial intermediation literature thereafter: relationship lenders can acquire information, knowledge and skills about firms' capital assets, helping firms in the event of distress and restructuring of their projects and thus enhancing the redeployment value of their capital assets. Crucially, the incentive of relationship lenders to acquire knowledge about firms' assets depends on their involvement in liquidity provision and, hence, on the stake they have in the successful restructuring of projects. The larger the share of a project financed by loans rather than by firms' cash holdings, the stronger the incentive for a relationship lender to acquire knowledge about the capital assets of the project. Thus, when demanding cash firms face a trade-off. On the one hand, larger precautionary cash holdings reduce their dependence on costly loans. On the other hand, firms' cash holdings dilute lenders' involvement in project financing and, hence, lenders' incentive to acquire knowledge about projects. Interestingly, exploiting the aforementioned Italian data, Figure 2 shows that, in line with this prediction of the model, in Italian local credit markets where credit relationships are more intense, and hence firms have keener interest to preserve credit relationships, firms tend to hold less cash relative to financial debt on average. ${ }^{3}$

After characterizing firms' and lenders' decisions, we study the aggregate effects of credit relationships. We first show that in equilibrium relationship finance entails a cost premium over firms' cash holdings: this relationship finance premium reflects firms' appetite for informed liquidity, that is, firms' desire to incentivize relationship lenders' knowledge acquisition effort by better involving them in project financing. In a region of parameters, this relationship finance premium can be suboptimally high in steady state. However, we find that when credit relationships are tight, the relationship finance premium can be suboptimally low and firms can overborrow in credit relationships and overinvest in their projects. In the latter scenario, the monetary authority can find it optimal to compensate for the underpricing of relationship loans and

\footnotetext{
${ }^{3}$ Cash is defined as cash and cash equivalents. Like in Figure 1, the data refer to the 1995-2003 period and the local intensity of credit relationships is the share of firms in the province with a close-by main bank.
} 
boost their cost by setting a positive policy rate, that is, departing from the Friedman rule.

We then examine the influence of credit relationships on the effects of shocks to the steady state through the interaction between firms' cash holdings, lenders' effort and the relationship finance premium. When economic conditions are relatively poor, tight credit relationships attenuate the effects of a negative real shock on firms' investment and output. In tight credit relationships, following the negative shock, lenders step up their knowledge acquisition effort to preserve their returns from liquidity provision and, on top of this, the relationship finance premium drops. However, if credit relationships are loose, the relationship finance premium rises following a negative shock, amplifying the effects of the shock on investment and output and the resulting welfare loss. This destabilizing effect of loose credit relationships arises even when the monetary authority adjusts the policy rate optimally in response to the shock.

Taken together, our results thus imply that while a loosening of credit relationships can ameliorate welfare, this loosening can hurt the stabilizing role of credit relationships, possibly turning them into a shock amplifier. To get a sense of this trade-off, after characterizing it analytically, we develop a numerical example calibrated on the aforementioned data on Italian firm-bank credit relationships. In the last part of the paper, we study whether credit policies (liquidity injections into lenders or into firms) influence the aggregate effects of credit relationships by altering the mix relationship loans-cash holdings. We find that credit policies that inject liquidity into lenders can enhance the welfare impact of credit relationships but, perhaps surprisingly, hardly restore a stabilizing role for loose credit relationships. Such a stabilizing role is better served by credit policies that inject liquidity into firms.

Before proceeding, it is useful to note that, while the model applies naturally to banks, it could also be applied to specialized financial intermediaries (e.g., finance companies or investment funds) which also engage in relationship finance. The remainder of the paper unfolds as follows. Section 2 relates the paper to prior literature. In Sections 3 and 4, we describe and solve the model. Section 5 studies the aggregate effects of credit relationships. We first characterize the impact of credit relationships on welfare and on the optimal monetary policy in steady state. We then study the impact of credit relationships on the resilience to shocks to the steady state. Section 6 examines how credit policies influence the aggregate effects of credit relationships. Section 7 concludes. Technical proofs are relegated to the Appendix. 


\section{Prior Literature}

This paper is related to search models of money with credit. ${ }^{4}$ In this literature, Rocheteau, Wright and Zhang (2018) and Rocheteau, Wong and Zhang (2018) are probably the most related papers. Rocheteau, Wright and Zhang (2018) consider a setting in which banks can extract surplus from firms' investments. Through precautionary money holdings, firms reduce their reliance on bank funding and banks' surplus extraction. Rocheteau, Wong and Zhang (2018) also explore the endogenous formation of lending relationships. Relative to these papers, we focus on the intensive margin (endogenous intensity) of credit relationships and investigate the interaction between banks' role as liquidity providers and their endogenous effort in acquiring knowledge, information, and skills about projects in a monetary economy. Banks' endogenous effort in acquiring knowledge and expertise about projects is indeed a key characterizing feature of relationship finance (Berger and Udell, 2002; Boot and Thakor, 2000; Berger and Udell, 2006). In particular, we specify relationship banks' acquisition of expertise following the approach of Diamond and Rajan (2000, 2001a, 2001b), where relationship banks' expertise materializes in collection and restructuring skills about projects. By analyzing the interaction between banks' liquidity provision and their endogenous knowledge acquisition effort (intensive margin of credit relationships), we uncover a complementary mechanism through which firms' money holdings can affect output and welfare. In our economy where banks' knowledge acquisition is non-contractible, while firms' money holdings reduce firms' reliance on costly bank credit, they also dilute banks' involvement in projects and hence their incentives to acquire knowledge and expertise about projects. By contrast, banks' liquidity provision motivates their knowledge acquisition inside credit relationships, that is, banks' effort and intermediated liquidity (credit) are complements. In this setting, factors that modify firms' money holdings affect banks' effort in credit relationships and the associated cost premium of relationship loans, affecting investment, output and welfare.

Financial intermediaries are also at the center of the literature that stresses financial frictions rather than trading frictions. Several studies investigate the financial disintermediation process following aggregate negative shocks (Gertler and Kiyotaki,

\footnotetext{
${ }^{4}$ See Lagos and Wright (2005) and, for comprehensive reviews, Nosal and Rocheteau (2011) and Lagos, Rocheteau and Wright (2017). Cavalcanti and Wallace (1999) and Gu, Mattesini, Monnet and Wright (2013) emphasize the role of banks as depository institutions and liquidity providers.
} 
2010; Gertler and Karadi, 2011; Diamond and Rajan, 2008; Lorenzoni, 2008). Yet, other studies highlight that in difficult times relationship lenders may protect firms on which they have acquired information (Beck, Degryse, de Haas and van Horen, 2018; Hoshi, Kashyap and Sharfstein, 1990; Jiangli, Unal and Yom, 2008; Ferri, Minetti and Murro, 2019; Boot and Thakor, 2000; Hachem, 2011). This paper can help reconcile these views showing that the composition of liquidity between loans and firms' cash holdings is crucial to determine whether credit relationships lead to a stronger or weaker resilience to aggregate negative shocks.

Finally, it is worth pointing out that, in specifying credit arrangements between banks and firms, we follow a large literature in banking on the extensive use of credit

line facilities (see, e.g., Berger and Udell, 2006, Campello, Giambona, Graham and Harvey, 2011, and references therein). As this literature stresses, by establishing banks' commitment to make liquidity available at a given interest rate, credit lines help protect firms from the risk that in difficult times banks extract surplus by threatening to withhold liquidity. In addition to capturing the diffusion of credit line facilities, our specification isolates the endogenous interaction between banks' knowledge acquisition effort and the composition loans-firms' cash holdings from the cash holdings motive driven by banks' threat to withhold liquidity (see, e.g., Rocheteau, Wright and Zhang, 2018, and the above-mentioned studies).

\section{The Model}

In what follows, we outline the environment. The two key features of our environment consist of information-intensive credit relationships and the presence of frictions in the restructuring process of firms' capital assets. We embed credit relationships in our environment following the specification in Diamond and Rajan (2000, 2001a, 2001b) and a broad financial intermediation literature thereafter. Frictions in the restructuring process of firms' capital, in turn, motivate the need for liquidity and for the knowledge and expertise of relationship lenders. We discuss these features in detail after outlining the environment. Figure 3 illustrates the timing of the economy. 


\subsection{Environment}

We consider an overlapping generations economy with a unit measure of entrepreneurs and a positive measure of bankers, whose size is determined by free entry. Entrepreneurs and bankers live for two periods, and discount across periods with a factor $\beta \in(0,1)$. We say that an agent is young in the first period of his life and old in the second period. The economy is also populated by a unit measure of workers who live for one period. There exist a perishable final good, a durable capital in fixed supply $K$, and fiat money, which grows at the gross rate $\tau$. Every period is divided in two stages, decentralized and centralized. There is a decentralized market (DM) that opens at the end of the decentralized stage, and a centralized market $(\mathrm{CM})$ that opens at the end of the centralized stage.

A number of activities take place during the centralized stage. First, agents consume and produce the final good, and the utility of consumption and disutility of production are linear. Old entrepreneurs also settle their outstanding debt with old bankers, while young entrepreneurs establish credit relationships with young bankers, as described below. Finally, agents interact in the CM, where money, final good and capital are traded. Capital can be used in projects, which start in the centralized stage and produce final good in the following centralized stage. There are two types of projects: a general project that can be implemented by any young entrepreneur; and a more productive, specialized project, that can only be implemented by a young entrepreneur if he receives an investment opportunity, an event with probability $\mu$. Projects succeed with probability $\pi$. If a general project with $k$ units of capital succeeds, it produces $\gamma k$ units of final good, while a successful specialized project produces $f(k)$, where $f^{\prime}>0$ and $f^{\prime \prime}<0$. We also assume $f^{\prime}(0)>\gamma$ and $k^{*}<K$, where $f^{\prime}\left(k^{*}\right)=\gamma$. If a project fails, it does not produce. Moreover, if a specialized project fails, its underlying capital needs to be restructured in order to be reused, otherwise it depreciates completely. General projects do not need to be restructured.

In the centralized stage, each young entrepreneur enters a credit relationship with a young banker. In a credit relationship, the banker commits to grant loans at a contractually agreed loan rate, as in a line of credit facility. If applicable, these loans will be granted in the following decentralized stage. When old, the banker also chooses her effort $\eta$ in acquiring information, knowledge and skills about the project of the entrepreneur. This effort will prove useful in the restructuring of failed projects, as 
explained below. Unlike her commitment to grant loans at an agreed upon rate, the old banker's effort is non-contractible and she can always force a renegotiation to extract part of the surplus generated by her effort. We let $\theta$ denote the banker's bargaining power in this renegotiation. The bargaining occurs after old entrepreneurs have made borrowing and lending decisions and after old bankers have chosen their effort.

The restructuring of failed specialized capital occurs in the DM and it requires the input of old entrepreneurs and workers. A worker incurs disutility $k$ to help restructure a project of size $k$, and terms of service between the entrepreneur and the worker are determined by a take it or leave it offer by the former to the latter. Meetings between entrepreneurs and workers in the DM are random, pairwise, and anonymous. As a result, only money can be used as a payment. ${ }^{5}$ An old entrepreneur may also incur an additional cost to restructure his project and, although old bankers do no directly participate in the DM, a banker participating in a credit relationship with an entrepreneur can help reduce this cost by acquiring information, knowledge and skills about the project. Precisely, if the old banker exerts effort $\eta$, her effort succeeds with probability $\eta^{\alpha}, \alpha \in(0,1)$, in which case the old entrepreneur does not incur any additional cost. If, instead, her knowledge acquisition effort fails, the old entrepreneur incurs an additional cost $C$ per unit of capital. The old banker's knowledge about the project also helps the financial side of the restructuring process, that is, it helps the old banker collect her loan: if her effort fails, the old banker incurs a cost $B$ per unit of real loans to ensure that the debt will be repaid.

Summary In every period, events first unfold in the decentralized stage and then in the centralized stage, as follows. At the beginning of the decentralized stage, old bankers exert effort in acquiring knowledge and skills about projects. After that, projects fail or succeed, and old entrepreneurs decide how much to borrow at the agreed loan rate from their outstanding credit facilities. Old entrepreneurs can also deposit idle liquidity with any old banker in the economy. Old bankers and old entrepreneurs then bargain over the expected surplus generated by the old banker's effort. Finally, the DM opens, workers enter the economy, randomly meet old entrepreneurs

\footnotetext{
${ }^{5}$ As we will see below, in our economy the demand for money comes from agents who choose specialized projects. The specialized nature of their capital prevents them from issuing claims against capital. One could also wonder whether IOUs issued by banks might be used as a medium of exchange in the DM. We rule this possibility out by positing that IOUs can be counterfeited and a worker cannot distinguish a genuine from a counterfeit. 
and restructure their capital. Workers stay in the economy until the end of the period. The economy then moves to the centralized stage, where old bankers and old entrepreneurs settle their outstanding debt. Young entrepreneurs and young bankers enter the economy and form credit relationships. These agents stay in the economy until the end of the following period. Finally, young entrepreneurs learn whether they received the opportunity to implement specialized projects and, together with workers and old entrepreneurs, participate in the CM, where money, final good and capital are traded.

\subsection{Discussion}

We embed credit relationships in a monetary economy by following the banking literature. Over the course of credit relationships, financial institutions invest in knowledge, information and skills about firms' projects (see, e.g., Diamond and Rajan, 2001; Boot and Thakor, 2000). This endogenous investment in developing expertise about projects is indeed a key characterizing feature of relationship finance (Berger and Udell, 2002; Boot and Thakor, 2000; Berger and Udell, 2006). The way we model credit relationships is akin to the specification in Diamond and Rajan (2000, 2001a, 2001b) where banks' expertise about projects materializes in banks' skills at collecting and restructuring firms' projects and capital assets. According to Diamond and Rajan (2001b), a relationship lender has seen the strategy of the project from its onset, can help find an agent who can restructure the project and reduce the cost of restructuring. Diamond and Rajan (2001a), in turn, argue that a relationship lender develops skills at reducing the cost of restructuring and enhancing the redeployment value of the assets. She knows how the business was built and where assets were bought, so she can help identify the second-best use(r) of the assets more precisely than anyone else. Several studies indeed find evidence that, thanks to their knowledge on firms' projects and assets gathered in credit relationships, financial institutions help firms face distress, reorganization and restructuring processes. They help firms make decisions about the timing of reorganization and asset liquidation and about the actions to be taken during distress; this, in turn, helps financial institutions recover their loans (Hoshi, Kashiap and Sharfstein, 1990; Höwer, 2016; Elsas, 2005; Chemmanur and Fulghieri, 1994; Shimizu, 2012). Financial institutions can also be involved in activities of asset liquidation and redeployment thanks to their knowledge and skills acquisition about 
firms' collateral assets and market redeployability (Diamond and Rajan, 2001b; Habib and Jonsen, 1999). Sheard (1994), Edwards and Fisher (1994) and De Cecco and Ferri (1996) document that in Japan, Germany and Italy during reorganizations relationship banks use bank contacts to facilitate capital asset disposal. In the 2010 EU-EFIGE survey on 15,000 European firms and in the 2006 Capitalia survey on 4,000 Italian firms, about $55 \%$ of the firms declared that the bank with the strongest credit relationship acquires information on the firm's collateral assets and their market. Gustafson, Ivanov and Meisenzahl (2017) and Cerqueiro, Ongena and Roszbach (2016) confirm these findings using loan officers' surveys.

We model the need for liquidity and for bankers' knowledge about projects by assuming that firms' restructuring takes place in a decentralized market. This specification captures the idea that the restructuring process of a firm and its capital assets entails trading frictions. A broad literature stresses, and finds evidence, that the secondary market for firms' capital assets is plagued by severe trading frictions (Ramey and Shapiro, 2001; Eisfeldt and Rampini, 2006; Gavazza, 2011; Shleifer and Vishny, 1992; Pulvino, 1998). Such frictions originate, for example, from capital specialization which forces firms to engage in a costly search process of suitable buyers. The availability of liquidity is critical for firms facing distress and restructuring because it allows firms to avoid fire sales of assets in the asset market, promptly maintain their capital and purchase used capital. Maksimovich and Phillips (2001) interpret the market for mergers of distressed firms as a decentralized market with trading frictions.

\section{Equilibrium}

We restrict attention to stationary monetary equilibria, i.e., equilibria where real balances, interest rates, bankers' effort and the distribution of capital between general and specialized projects are constant. Besides, we use the Fisher condition to rewrite the gross rate of the money supply $\tau$ in terms of the nominal interest rate $i$ on an illiquid bond, i.e.,

$$
i=\frac{\tau-\beta}{\beta}
$$

The nominal interest $i$ is the primary policy instrument available to the monetary authority.

Let us start with the problem of a young entrepreneur participating in the CM 
who did not receive the opportunity to implement the specialized project. Letting $\phi_{k}$ $\left(\phi_{m}\right)$ denote the price of capital (money) in units of final good, the young entrepreneur chooses capital $k$ and money holdings $m$ to maximize

$$
-\phi_{k} k-\phi_{m_{-1}} m+\beta \pi \gamma k+\beta \phi_{k} k+\beta \phi_{m}\left(1+i_{d}\right) m
$$

where $i_{d}$ is the interest rate on deposits. In words, the young entrepreneur incurs a disutility $\phi_{k} k+\phi_{m} m$ to acquire capital and money. If successful, the general project produces $\gamma k$ units of final good in the following CM and, since capital does not depreciate, the value of $k$ units of capital in the following $\mathrm{CM}$ is $\phi_{k} k$. In equilibrium, a positive and finite demand for capital requires

$$
-\phi_{k} k+\beta \pi \gamma k+\beta \phi_{k} k=0
$$

which implies

$$
\phi_{k}=\frac{\beta}{1-\beta} \pi \gamma
$$

Thus, the price of one unit of capital equals the present value of the expected stream of final good that can be produced with this unit. As for money holdings, since general projects do not need restructuring, any money brought into the DM by the entrepreneur is simply deposited with a banker. In equilibrium, it must also be the case that $\phi_{m_{-1}} \geq \beta\left(1+i_{d}\right) \phi_{m}$, otherwise there would be an infinite demand for money. Moreover, free entry of bankers implies that bankers compete for deposits and the ensuing deposit rate satisfies $\phi_{m_{-1}}=\beta\left(1+i_{d}\right) \phi_{m}$, which can be rewritten as

$$
i_{d}=i
$$

To obtain (2) we use the Fisher condition and the fact that, in a stationary equilibrium with constant real balances, $\phi_{m_{-1}} M_{-1}=\phi_{m} M$. According to (2), the opportunity cost $i$ of carrying money into the DM is equal to the benefit $i_{d}$ of depositing money with a banker. Therefore, an entrepreneur with a general project has no strict incentive to demand money. Accordingly, henceforth we set to zero the demand for money under the general project.

Let us now consider the problem of a young entrepreneur who received the opportunity to implement the specialized project. We claim that the entrepreneur chooses to implement the specialized project and to restructure its underlying capital in case 
the project fails. We later show that this is true in equilibrium. In the CM, the young entrepreneur chooses capital $k$ and money holdings $m$ to maximize

$$
-\phi_{k} k-\phi_{m_{-1}} m+\beta V(k, m)
$$

where $V(k, m)$ is the endogenous value of entering the DM with a specialized project of size $k$ and with $m$ units of money. Henceforth, to ease exposition, we will say that an entrepreneur uses specialized capital when he uses capital in a specialized project. The first order conditions are

$$
\phi_{m_{-1}}=\beta V_{m}(k, m),
$$

and

$$
\phi_{k}=\beta V_{k}(k, m) .
$$

To determine $V(k, m)$, we proceed by backward induction, starting with the surplus generated by the old banker's effort in acquiring knowledge and skills about the project. If the old banker exerts effort $\eta$, there is a probability $\eta^{\alpha}$ that her effort will succeed, in which case there will be no restructuring cost. There is a complementary probability that her effort will fail and the restructuring of the project will cost $C k$. The old banker's knowledge about the project also helps to ensure that the old entrepreneur will settle his debt. Indeed, since the entrepreneur borrows $k-\phi_{m} m$ from the banker to gather enough liquidity to pay the worker who will help in the restructuring, if the banker's effort fails she incurs a cost $\left(k-\phi_{m} m\right) B$ to ensure the loan repayment. Taken together, the overall surplus generated by the old banker if she exerts effort $\eta$ is given by

$$
S^{\eta}(k, m)=\eta^{\alpha}\left[C k+\left(k-\phi_{m} m\right) B\right] .
$$

The old banker chooses her effort anticipating that she will extract a fraction $\theta$ of the surplus. Precisely, she solves

$$
\max _{\eta}\left\{-\eta k+(1-\pi) \theta S^{\eta}(k, m)\right\}
$$

and her effort satisfies

$$
\widehat{\eta} \equiv \eta\left(\frac{k-\phi_{m} m}{k}\right)=\left\{\alpha(1-\pi) \theta\left[C+\frac{k-\phi_{m} m}{k} B\right]\right\}^{\frac{1}{1-\alpha}} .
$$


Thus, the banker's effort increases with her involvement in the financing of the project, as measured by $\frac{k-\phi_{m} m}{k} .6$ The extent to which the banker's participation affects her effort depends on $B$, the direct stake that the banker has in the success of restructuring for obtaining the debt repayment. We will then interpret $B$ as a measure of bankers' stake in credit relationships or, more succinctly, the tightness of credit relationships.

We can now write down $V(k, m)$. There is a probability $\pi$ that the project succeeds. In this case an old entrepreneur deposits his money, produces $f(k)$ units of final good and carries $k$ units of capital into the CM. There is a complementary probability $1-\pi$ that the project fails, in which case the payoff of the old entrepreneur is

$$
V^{\eta}(k, m)=-\left(1+i_{\ell}\right)\left(k-\phi_{m} m\right)-C k+(1-\theta) S^{\eta}(k, m)
$$

where the first two terms on the right-hand side correspond to the outside option of the old entrepreneur if he chooses not to use the skills of the banker. In this case, he still needs to borrow $k-\phi_{m} m$ at the contractually agreed interest rate $i_{\ell}$ to pay for the restructuring of capital. Putting these terms together,

$$
V(k, m)=\pi\left[f(k)+\left(1+i_{d}\right) \phi_{m} m\right]+(1-\pi) V^{\eta}(k, m)+\phi_{k} k
$$

We can now substitute (5) in (3) and (4) to solve for the demand for money and specialized capital.

Demand for money The marginal benefit of money is given by

$$
V_{m}(k, m)=\left[\pi\left(1+i_{d}\right)+(1-\pi)\left(1+i_{\ell}\right)\right] \phi_{m}-(1-\pi)(1-\theta) \frac{\widehat{\eta}^{\alpha}}{1-\alpha} B \phi_{m}
$$

Bringing money into the decentralized stage allows an entrepreneur to obtain a higher return on deposits, and to save any extra cost of loans. This captures the precautionary motive for holding cash: young entrepreneurs demand cash to tackle liquidity needs in case of distress without relying excessively on costly bank loans. However, bringing

\footnotetext{
${ }^{6} \mathrm{~A}$ broad empirical literature captures the intensity of a credit relationship through the share of liquidity provided by the lender (Sufi, 2007; Norden and Weber, 2010; Ongena, Tümer-Alkan and von Westernhagen, 2012; Sette and Gobbi, 2015; Guiso and Minetti, 2010). And several studies find that information acquisition is stronger when the lender finances a larger share of the firm's liquidity needs (Elsas, 2005; Sette and Gobbi, 2015; Li, Saunders and Shao, 2015; Gustafson, Ivanov and Meisenzahl, 2017). The share of liquidity provided by the bank is reputed by German loan officers as the main measure of the intensity of a credit relationship (Elsas, 2005). 
more cash into the decentralized stage, and hence borrowing less from the banker, reduces the banker's involvement in the project and, hence, the banker's incentive to acquire knowledge and skills about the project. This captures the cost of internal liquidity in diluting the ties between entrepreneurs and bankers, which are built through liquidity provision by bankers in credit relationships. Clearly, if bankers' knowledge acquisition effort was contractible, bankers' effort and entrepreneurs' cash holdings would be separable. However, since bankers' effort is non-contractible, bankers' knowledge acquisition effort is intrinsically related to bankers' involvement in project financing and, hence, to entrepreneurs' cash holdings.

Substituting $V_{m}(k, m)$ in $(3)$, we obtain the demand for money in the CM

$$
1+i=\left(1+i_{\ell}\right)-(1-\theta) \frac{\widehat{\eta}^{\alpha}}{1-\alpha} B
$$

In the expression above, the old bankers' effort $\widehat{\eta}$ depends on the relative demand of loans, $\frac{k-\phi_{m} m}{k}$. Thus, the equation gives the relative demand for loans as a decreasing function of the loan rate. We can pin down the equilibrium value of the relative demand for loans by looking at the relative supply of loans. The total loan supply is $\mu \pi M$, i.e., all the money deposited in banks by successful entrepreneurs undertaking the specialized project. This money is lent to a measure $(1-\pi) \mu$ of failed entrepreneurs undertaking the specialized project, which implies that each receives a loan of size $\pi M /(1-\pi) \mu$. Since these entrepreneurs also hold an amount $M / \mu$ of money, in equilibrium the relative supply of loans is

$$
\frac{k-\phi_{m} m}{k}=\frac{\pi M /(1-\pi) \mu}{\pi M /(1-\pi) \mu+M / \mu}=\pi .
$$

Lemma 1 summarizes our result.

Lemma 1 The equilibrium loan rate satisfies

$$
i_{\ell}=i+\underbrace{(1-\theta) \frac{\widehat{\eta}^{\alpha}}{1-\alpha} B}_{R F P} .
$$

where

$$
\widehat{\eta}=[\alpha(1-\pi) \theta(C+\pi B)]^{\frac{1}{1-\alpha}}
$$

The loan rate is the sum of the opportunity cost $i$ of the entrepreneur's money holdings and of a wedge that we label "relationship finance premium" (RFP). This 
premium stems from relationship bankers' ability to acquire knowledge, information and skills about projects and it reflects entrepreneurs' attempt to motivate additional effort of their relationship lenders by better involving them in project financing, and the resulting pressure this puts on loan demand and on the loan rate. Note that, following the Friedman rule and setting the nominal interest rate $i$ equal to zero leads to a zero deposit rate, but not to a zero loan rate. Note also that the RFP vanishes if a banker extracts all the surplus of her effort. Intuitively, an entrepreneur has an incentive to borrow at a higher cost inside a credit relationship only if he benefits from the banker's effort. The RFP also vanishes if a banker extracts no surplus from her effort, since she will have no incentive to acquire knowledge and skills about the project in this case. In what follows, to ensure an interior solution for the effort of bankers, we assume that

$$
A 1: 1>\alpha(1-\pi) \theta(C+\pi B)
$$

Demand for capital We now determine the demand for specialized capital $k$. The marginal benefit of specialized capital at the beginning of the decentralized stage is

$$
V_{k}(k, m)=\pi f^{\prime}(k)+(1-\pi) V_{k}^{\eta}(k, m)+\phi_{k}
$$

where

$$
V_{k}^{\eta}(k, m)=-\left(1+i_{\ell}\right)-\left\{C-(1-\theta)\left[C+\left(1+\frac{\alpha}{1-\alpha} \frac{\phi_{m} m}{k}\right) B\right] \widehat{\eta}^{\alpha}\right\} .
$$

An additional unit of capital brought into the CM at the end of the period gives $\phi_{k}$ units of final good. If the project succeeds, an additional unit of capital also produces $f^{\prime}(k)$. If, instead, the project fails, the old entrepreneur borrows an additional amount of real balances $k-\phi_{m} m$, at an interest rate $i_{\ell}$, in order to have enough liquidity to pay the restructuring effort of the worker. For the additional unit of capital the old entrepreneur also expects to sustain a restructuring cost of $C$ minus her share of the surplus generated by the old banker's effort. The first order condition for the demand for specialized capital $\phi_{k}=\beta V_{k}\left(k_{+1}, m_{+1}\right)$ then reads

$$
\frac{\pi}{1-\pi}\left[f^{\prime}(\widehat{k})-\gamma\right]=1+i_{\ell}+C-(1-\theta)\left[C+\left(1+\frac{\alpha}{1-\alpha} \frac{\phi_{m} m}{k}\right) B\right] \widehat{\eta}^{\alpha} .
$$

An increase in the loan rate increases the cost of gathering funds to make payments in the DM, which reduces the size of the project the young entrepreneur is willing to 
undertake. In turn, the larger the surplus from the old banker's effort, the stronger the incentive to choose a larger project.

Using (6) and (7), we can rewrite the demand for specialized capital as

$$
\frac{\pi}{1-\pi}\left[f^{\prime}(\widehat{k})-\gamma\right]=1+i+\alpha \pi \operatorname{RFP}+\left[1-(1-\theta) \widehat{\eta}^{\alpha}\right] C .
$$

Observe that in equilibrium a higher effort of the banker tends to increase the demand for specialized capital since it reduces the restructuring cost in case of distress. On the other hand, a higher effort of the banker also leads to a higher loan rate, which tends to counteract this effect. ${ }^{7}$

Finally, we can use (6) and (9) to pin down the equilibrium price of money, i.e.,

$$
\phi_{m}=\frac{(1-\pi) \widehat{k}}{M}
$$

Lastly, we need to check our claim that a young entrepreneur chooses to implement the specialized project and to restructure its underlying capital in case the project fails. Substituting for the equilibrium values of specialized capital, interest rates, bankers' effort, real balances, and the price of capital, we obtain that a specialized project dominates a general project if and only if

$$
\frac{\pi}{1-\pi}\left[\frac{f(\widehat{k})}{\widehat{k}}-\gamma\right]>1+i+\alpha \pi \mathrm{RFP}+\left[1-(1-\theta) \widehat{\eta}^{\alpha}\right] C,
$$

which is implied by (9). In the Appendix, we also provide sufficient conditions ensuring that it is always optimal to restructure. ${ }^{8}$ Proposition 1 summarizes our results.

Proposition 1 There exists a unique stationary monetary equilibrium. It is given by a list $\left\{\phi_{k}, \phi_{m}, i_{d}, i_{\ell}, \widehat{\eta}, \widehat{k}\right\}$ where $\phi_{k}$ is given by (1), $i_{d}$ is given by (2), $i_{\ell}$ is given by (7), $\widehat{\eta}$ is given by (8), $\widehat{k}$ is given by (9), and $\phi_{m}$ is given by (10).

\section{Aggregate Effects of Credit Relationships}

In this section, we study the aggregate effects of credit relationships. We first investigate their effects on welfare and on the optimal monetary policy in steady state.

\footnotetext{
${ }^{7}$ Note that, since $\widehat{k}<k^{*}$, it is always the case that $\widehat{k}<K$.

${ }^{8}$ Intuitively, we need an upper bound on the policy $i$ set by the monetary authority to make it not too costly to acquire liquidity to use in the DM in ${ }_{16}$ case the project fails.
} 
We next examine how credit relationships influence the effects of shocks to the steady state. In the last part of the section, we illustrate the analytical results with a numerical example calibrated on the aforementioned data on Italian firms and credit relationships.

\subsection{Steady state welfare and optimal policy}

In our economy, funds used in the restructuring of failed capital are transfers between agents, thus they do not affect welfare. Now, while the costs $C$ of the operational restructuring necessary for continuing to use assets generally constitute resource losses (e.g., time for reorganization of the assets, effort for closing plants or shifting production to new locations, human and other resources invested in the reorganization), the costs associated with the financial restructuring ( $B$ per unit of real loan) incurred by bankers can be interpreted as a real cost or as a transfer (e.g., legal fees, expenses for professionals, and litigation fees). In what follows, we let $\phi \in(0,1)$ denote the real fraction of the aggregate cost $\pi B$ of financial restructuring. Thus, welfare is

$$
\mathcal{W}=\underbrace{\pi \gamma+\mu \pi[f(k)-\gamma k]}_{\text {Projects' Output }(\mathrm{Y})}-\underbrace{\mu(1-\pi)\left[\frac{\eta}{1-\pi}+\left(1-\eta^{\alpha}\right)(C+\phi \pi B)\right]}_{\text {Restructuring and Knowledge Acquisition Costs }},
$$

that is, the total output of general and specialized projects $(Y)$ net of costs of restructuring and knowledge acquisition. The knowledge and skills acquisition effort of bankers that maximizes welfare is

$$
\eta_{\text {planner }}=[\alpha(1-\pi)(C+\phi \pi B)]^{\frac{1}{1-\alpha}}
$$

Comparing (12) with (8) we observe that, on the one hand, a banker exerts less effort than the planner because she does not extract its full surplus. On the other hand, since the banker's effort reduces her private cost of ensuring debt repayment, she may have an incentive to exert excessive effort. We obtain that $\widehat{\eta}>\eta_{\text {planner }}$ if and only if

$$
\theta>\frac{C+\phi \pi B}{C+\pi B}
$$

In turn, the level of specialized capital that maximizes welfare is

$$
\frac{\pi}{1-\pi}\left[f^{\prime}\left(k_{\text {planner }}\right)-\gamma\right]=\frac{\eta_{\text {planner }}}{1-{ }_{17}}+\left(1-\eta_{\text {planner }}^{\alpha}\right)(C+\phi \pi B) .
$$


The problem of the monetary authority consists of choosing the nominal interest rate $i$ that maximizes welfare subject to the bankers' effort, given by (8), as well as the entrepreneurs' demand for specialized capital, given by (9). Since $\widehat{\eta}$ does not depend on $i$, the monetary authority takes $\widehat{\eta}$ as given and solves a constrained problem, i.e., it chooses $i$ to maximize $\mathcal{W}(k, \widehat{\eta})$, evaluated at $\widehat{k} \equiv k(i, \widehat{\eta})$, where $\widehat{k}$ solves $(9)$. The first-order condition to its problem implies

$$
\frac{\pi}{1-\pi}\left[f^{\prime}(\widehat{k})-\gamma\right]-\left[\frac{\widehat{\eta}}{1-\pi}+\left(1-\widehat{\eta}^{\alpha}\right)(C+\phi \pi B)\right] \geq 0,
$$

with the inequality strict if $i=0$. Intuitively, if (15) is strictly positive, the demand for specialized capital is inefficiently low, and it is optimal to follow the Friedman rule and set the nominal interest rate as low as possible to increase the capital demand. It is, instead, optimal to set a positive nominal interest rate and deviate from the Friedman rule if (15) is satisfied at equality. In this case, using (9), the optimal interest rate is

$$
1+i=\frac{\widehat{\eta}}{1-\pi}+\left(1-\widehat{\eta}^{\alpha}\right)(C+\phi \pi B)-\left[1-(1-\theta) \widehat{\eta}^{\alpha}\right] C-\alpha \pi \mathrm{RFP} .
$$

Importantly for our analysis, a deviation from the Friedman rule is optimal if $B$ is relatively large, that is, if bankers' stake in credit relationships is large (credit relationships are tight). In this case, the RFP is suboptimally low relative to bankers' effort $\widehat{\eta}$, which, for a zero nominal interest rate, leads to an excessive equilibrium demand for specialized capital $\widehat{k} \equiv k(i, \widehat{\eta})$ relative to the constrained optimal level. In order to taper off this suboptimally high demand, the monetary authority needs to increase the nominal interest rate and counteract the underpricing of relationship loans, so as to equate the equilibrium demand for specialized capital to its constrained optimal level $k(\widehat{\eta})$. Inspection of (16) shows that the optimal interest rate varies non-monotonically with bankers' bargaining power $\theta$, i.e., it is optimal to increase the interest rate when $\theta$ is either relatively small or relatively large. Again, in such cases the RFP is suboptimally low: entrepreneurs' appetite for relationships loans is low either because they extract little surplus from bankers' effort (high $\theta$ ) or because bankers have reduced propensity to exert effort (low $\theta$ ). In both cases, the suboptimally low RFP induces an excessive demand for specialized capital, making it optimal to increase the nominal interest rate in order to taper off this demand. Proposition 2 summarizes our result.

Proposition 2 The constrained optimal level of specialized capital can only be implemented if (15) holds with equality, which occurs when bankers' stake in credit relation- 
ships (B) is high. In this case, the RFP is suboptimally low and the optimal nominal interest rate deviates from the Friedman rule, being given by (16). If, instead, bankers' stake in credit relationships $(B)$ is low, the optimal nominal interest rate is given by the Friedman rule.

Figure 4 illustrates the proposition with the help of a calibrated numerical example. The calibration is performed by exploiting the aforementioned data set on Italian firms (see Section 5.3 below for details). For any state of economic conditions, captured by the probability of project success $\pi$, when bankers' stake in credit relationships $(B)$ is high, above the FR curve, the optimal intervention deviates from the Friedman rule. The Friedman rule instead holds when $B$ is below the $F R$ curve.

\subsection{Shocks}

We now examine the influence of credit relationships on the effects of shocks to the steady state. We consider permanent changes in economic conditions, captured by changes in the probability of project success $\pi$. Establishing whether credit relationships attenuate or amplify the effect of real shocks on specialized capital demand yields immediate implications for output and welfare. ${ }^{9}$ Denoting by $\widehat{Y}=$ $\pi \gamma+\mu \pi[f(\widehat{k})-\gamma \widehat{k}]$ the equilibrium output of projects, the percent output effect of $\pi$ on $\widehat{Y}$ is

$$
\frac{\partial \widehat{Y}}{\partial \pi} / \widehat{Y}=1+\frac{\partial \widehat{k}}{\partial \pi} \frac{\mu\left[f^{\prime}(\widehat{k})-\gamma\right]}{\gamma+\mu[f(\widehat{k})-\gamma \widehat{k}]}
$$

which positively depends on the effect on specialized capital demand, $\partial \widehat{k} / \partial \pi$. Thus, a larger drop in specialized capital demand in response to a negative shock will result in a larger output drop. As for welfare $(\widehat{\mathcal{W}})$, when the Friedman rule holds, for example, the equilibrium demand for specialized capital in (9) is lower than the constrained optimal level in (15). Thus, a larger drop in specialized capital demand will also result in a larger welfare loss.

\footnotetext{
${ }^{9}$ The literature has studied empirically the effect of credit relationships in attenuating or amplifying shocks (see, e.g., Sette and Gobbi, 2015; Hoshi, Kashyap and Sharfstein, 1990).
} 
From (9) the effect of $\pi$ on specialized capital demand is given by

$$
\frac{\partial \widehat{k}}{\partial \pi}=-\frac{1-\pi}{\pi f^{\prime \prime}(\widehat{k})}[\frac{f^{\prime}(\widehat{k})-\gamma}{(1-\pi)^{2}}-\underbrace{\alpha\left(1+\epsilon-\frac{1-\alpha}{\alpha} \frac{C}{\pi B} \epsilon\right) \operatorname{RFP}}_{\text {Effect of Credit Relationships }}-\frac{\partial i}{\partial \pi}],
$$

where

$$
\epsilon=\frac{\partial \mathrm{RFP}}{\partial \pi} \frac{\pi}{\mathrm{RFP}}=\alpha \frac{\partial \widehat{\eta}}{\partial \pi} \frac{\pi}{\widehat{\eta}}=-\frac{\alpha}{1-\alpha}\left(\frac{\pi}{1-\pi}-\frac{\pi B}{C+\pi B}\right)
$$

and $\partial i / \partial \pi$ denotes the change in the policy rate. In what follows, we first take the policy rate as given $(\partial i / \partial \pi=0)$; this also encompasses the case in which the Friedman rule holds and the policy rate is optimally set at zero. At the end of the section, we study the case in which the Friedman rule does not hold and the monetary authority conducts active monetary policy, adjusting the policy rate in response to the shock.

There are two effects of a decrease in $\pi$. First, it makes more costly to choose specialized projects, since their capital needs to be restructured in case of project failure. This purely technological effect of capital specificity is captured by the first term in brackets in (17). Second, the decrease in $\pi$ also affects $\widehat{k}$ through its impact on bankers' effort and the RFP. This constitutes the mechanism of influence of credit relationships and is captured by the second term in brackets in (17). The impact of the decrease in $\pi$ on specialized capital demand will depend on the sign and magnitude of the effect of credit relationships. Precisely, if

$$
\frac{\pi B}{C} \geq \frac{1-\alpha}{\alpha} \frac{\epsilon}{1+\epsilon}
$$

credit relationships attenuate the negative effect of a decrease in $\pi$ on the demand for specialized capital $\widehat{k}$. Otherwise, credit relationships amplify the negative effect. Which outcome emerges critically depends on whether the RFP drops or rises with the decrease in $\pi$. If the RFP drops, then (19) is always satisfied. If, instead, the RFP rises there exists $\bar{\alpha} \in(0,1)$ such that (19) is satisfied if and only if $\alpha \leq \bar{\alpha} .{ }^{10}$ Proposition 3 formalizes our result.

Proposition 3 i) If either $\pi>1 / 2$ or $\pi<1 / 2$ and $B<C /(1-2 \pi)$ (bankers' stake in credit relationships is low), the RFP behaves countercyclically, rising after a decrease

\footnotetext{
${ }^{10}$ The value of $\bar{\alpha}$ is given by $\left[1+\frac{C}{\pi B}\left(\frac{\pi}{1-\pi}-\frac{\pi B}{C+\pi B}\right)\right] /\left[1+\left(\frac{C}{\pi B}+1\right)\left(\frac{\pi}{1-\pi}-\frac{\pi B}{C+\pi B}\right)\right]$, and it is trivially obtained by reorganizing (19) and isolating $\alpha$ in terms of the remaining parameters.
} 
in $\pi$. In this case, there exists $\bar{\alpha} \in(0,1)$ such that, if $\alpha>\bar{\alpha}$, credit relationships amplify a negative shock, while the opposite happens if $\alpha \leq \bar{\alpha}$. (ii) If $\pi<1 / 2$ and $B>C /(1-2 \pi)$ (bankers' stake in credit relationships is high), the RFP behaves procyclically, dropping after a decrease in $\pi$. In this case, credit relationships always dampen a negative shock.

Proposition 3 shows that when the pre-shock economic conditions are good $(\pi$ is high) credit relationships amplify a shock to $\pi$. When, instead, the pre-shock economic conditions are relatively poor ( $\pi$ is low), credit relationships are stabilizing if they are tight enough ( $B$ is high) while they can be destabilizing if they are loose ( $B$ is low). Figure 4 illustrates the proposition continuing with the numerical example used to illustrate Proposition 2. Credit relationships are potentially destabilizing when bankers' stake in credit relationships $(B)$ is below the $S R$ curve, while they are stabilizing when it is above the $S R$ curve.

To better understand Proposition 3, we need to look at how relationship bankers' incentive to exert effort changes following a shock and the resulting impact on the RFP. Old bankers tend to have a stronger incentive to acquire knowledge and skills about projects when projects' probability of failure increases ( $\pi$ drops), as this increases the usefulness of their effort in the event of firm restructuring. However, bankers' effort incentives tend to weaken when the drop in $\pi$ reduces the equilibrium value of loans over cash and hence bankers' involvement in projects. ${ }^{11}$ When bankers care a lot about their project involvement (their stake $B$ is high and credit relationships are tight) the second effect dominates, reducing entrepreneurs' appetite for relationship loans and, hence, the RFP. When instead $B$ is low, the first effect dominates, increasing entrepreneurs' appetite for relationship loans and the RFP.

In the above analysis, the policy rate $i$ was constant. We now consider the case in which the Friedman rule does not hold and the monetary authority actively adjusts the policy rate in response to the shock $\widehat{i}>0$ and $\partial i / \partial \pi=\partial \widehat{i} / \partial \pi)$. As shown in

\footnotetext{
${ }^{11}$ The loan supply shrinks due to a contraction in the amount of intermediated liquidity. The loan demand also shrinks as a result of an increase in firms' precautionary cash holdings. Both these phenomena have been extensively documented in many downturns, including the Great Recession. Recently, several studies have also provided hard evidence of a significant contraction in firms' borrowings relative to firms' internal liquidity during downturns (see, e.g., Covas and den Haan, 2011, and references therein).
} 
Section 5.1, the nominal interest rate does not affect bankers' effort and the RFP and, hence, does not directly interfere with the stabilizing or destabilizing effect of credit relationships studied above (see the second and third term in brackets in (17)). The optimal response of the policy rate is given by

$$
\frac{\partial \widehat{i}}{\partial \pi}=\left(1-\widehat{\eta}^{\alpha}-\alpha \widehat{\eta}^{\alpha} \frac{\partial \widehat{\eta}}{\partial \pi} \frac{\pi}{\widehat{\eta}}\right) \phi B+\theta\left[\left(1-\frac{1}{1-\alpha} \frac{1-\theta}{\theta}\right)(1+\epsilon) \frac{\pi B}{C}-\frac{1-\alpha}{\alpha} \epsilon\right] \frac{\alpha \widehat{\eta}^{\alpha}}{\pi} C .
$$

For example, if $\phi=0$, a negative shock to $\pi$ leads to a decrease in the optimal nominal interest rate if and only if

$$
\frac{\pi B}{C}>\frac{1}{1-\frac{1}{1-\alpha} \frac{1-\theta}{\theta}} \frac{1-\alpha}{\alpha} \frac{\epsilon}{1+\epsilon}
$$

which is implied by (19). Thus, whenever credit relationships attenuate the effect of a negative shock for any given policy rate, the optimal monetary intervention complements their stabilizing role.

\subsection{A calibrated example}

Propositions 2 and 3 show that the aggregate effects of credit relationships can involve a trade-off. Proposition 2 shows that tight credit relationships can lead to a suboptimally low RFP and call for a departure from the Friedman rule. On the other hand, Proposition 3 shows that loose credit relationships can lead to a countercyclical RFP and lower resilience to real shocks. Figure 4 illustrates this trade-off. The parameters used to plot the FR and SR frontiers in the figure are calibrated based on the aforementioned data on Italian firms. Italian businesses are particularly suitable for a calibrated numerical example as credit relationships are pervasive in the Italian credit sector (Degryse, Kim and Ongena, 2009). The firm-level data refer to a sample of 4,289 manufacturing firms with no less than 10 employees observed in 2003. They are drawn from the 2003 wave of the Survey on Italian Manufacturing Firms carried out by a major Italian banking group, Capitalia. We complement the survey with a variety of other data sources. In the 2003 Capitalia survey, the average loan rate $\left(i_{\ell}\right)$ equals $5.9 \% .^{12}$ We set the deposit rate $(i)$ to $3.3 \%$, as reported by Banca d'Italia

\footnotetext{
${ }^{12}$ As it is often the case, the survey does not directly report loan rates. Following previous studies, we compute the loan rate as the ratio of interest expenses of a firm over its total borrowing from banks.
} 
(2003). Banks' bargaining power $(\theta)$ is set to 0.16 , as in Rocheteau, Wright and Zhang (2018). To pick the values of $C$ and $B$, we look at data on the expenses of Italian firms for operational and financial restructuring. Data from the Italian National Institute of Statistics report an average of $23 \%$ for the ratio of such expenses over the total value of firm assets (ISTAT, 2007). To allocate such expenses to operational and financial restructuring costs, we refer to the results of Branch (2002), that show that about one third of such expenses generally go to financial restructuring $(B)$ and two thirds go to operational restructuring $(C)$. We set the rate of return on general projects $(\gamma)$ to $10 \%$. The probability that a firm does not incur any form of restructuring $(\pi)$ is set at $60 \%$. Using equations $7-9$, we then pick a value of $\alpha$ of 0.47 to match the RFP (spread between loan rate and deposit rate, $i_{\ell}-i$ ) of $2.6 \%$ implied by the chosen loan and deposit rates. Given these parameter choices, equation (15) and the conditions in Proposition 2 imply the FR and SR frontiers plotted in Figure 4.

In Figure 5, employing the same data sources, we provide suggestive evidence on the patterns of the RFP predicted by the model. For this figure, we consider three waves of the Capitalia survey, 1997, 2000, and 2003, covering a total of nine years (19952003), 9,735 firms and 40,047 firm-year observations. The firms are partitioned in 99 Italian local credit markets (provinces). ${ }^{13}$ The left panel of the figure plots the average loan-deposit rate spread (RFP) in a province against the average strength of credit relationships in the province, measured as the share of firms that declare to have a close-by (within province) main bank (Degryse, Kim and Ongena, 2009). ${ }^{14}$ In line with the result in Lemma 1, we detect a positive relationship between the average RFP and the local intensity of credit relationships. The right panel of the figure plots the average correlation between the RFP and the provincial output (GDP) against the average strength of credit relationships in the province. We detect a positive relationship between the procyclicality of the spread and the local intensity of relationships. This is consistent with Proposition 2, which predicts a more procyclical RFP when credit

\footnotetext{
${ }^{13}$ Provinces are geographical entities similar in size to U.S. counties.

${ }^{14}$ The empirical banking literature stresses the reliability of the bank-firm distance for measuring the structural strength of credit relationships in the data (see Degryse, Kim and Ongena, 2009, for a review). First, the bank-firm distance is highly correlated with other indicators of credit relationship strength. Second, it suffers less than other indicators from the risk of being contaminated by aspects not directly related to the relationship strength. For these reasons, in empirical studies it is sometimes used as an instrument for other indicators of relationship strength.
} 
relationships are stronger (i.e., that stronger credit relationships are more stabilizing).

\section{Credit Policy}

We now study how credit policies influence the aggregate effects of credit relationships. In response to the Great Recession, monetary authorities have implemented credit policies in the form of direct liquidity injections into the banking sector and into the business sector. The effects of these policies have reverberated over several years. To mimic these policies, we now let the monetary authority transfer money directly to old bankers and entrepreneurs with failed specialized projects in the decentralized stage, besides carrying out monetary injections in the CM. Unlike injections in the $\mathrm{CM}$, injections in the decentralized stage may influence bankers' effort and the RFP by altering the mix relationship loans-cash holdings.

The gross growth rate of money $\tau$ is now the sum between $\tau_{1}$, the money injected in the $\mathrm{CM}$, and $\tau_{2}=\tau_{2}^{e}+\tau_{2}^{b}$, the money injected to failed entrepreneurs $\left(\tau_{2}^{e}\right)$ and bankers $\left(\tau_{2}^{b}\right)$ in the DM. In equilibrium an old entrepreneur with a failed specialized project will hold $\tau_{1} M / \mu+\tau_{2}^{e} M /(1-\pi) \mu$ units of money to the DM, i.e., the money brought from the $\mathrm{CM}$ and the transfer received in the decentralized stage. In turn, old bankers will extend loans in the amount of $\pi \tau_{1} M+\tau_{2}^{b} M$, i.e., the money deposited by successful entrepreneurs and that injected by the monetary authority in the DM. Thus, the relative supply of loans is now

$$
\frac{\left(\pi \tau_{1} M+\tau_{2}^{b} M\right) /(1-\pi) \mu}{\left[\pi \tau_{1} M+\tau_{2}^{b} M+(1-\pi) \tau_{1} M+\tau_{2}^{e} M\right] /(1-\pi) \mu}=\pi\left(1-\tau^{\mathrm{E}}\right)+(1-\pi) \tau^{\mathrm{B}}
$$

where $\tau^{\mathrm{E}}=\frac{\tau_{2}^{e}}{\tau}$ denotes the share of liquidity directly injected into failed entrepreneurs and $\tau^{\mathrm{B}}=\frac{\tau_{2}^{b}}{\tau}$ denotes the share of liquidity directly injected into bankers. The equilibrium effort of a banker is now

$$
\eta_{\mathrm{C}}=\left\{\alpha(1-\pi) \theta\left\{C+\left[\pi\left(1-\tau^{\mathrm{E}}\right)+(1-\pi) \tau^{\mathrm{B}}\right] B\right\}\right\}^{\frac{1}{1-\alpha}},
$$

which is increasing in $\tau^{\mathrm{B}}$ but decreasing in $\tau^{\mathrm{E}}$. In turn, the equilibrium loan rate becomes

$$
i_{\ell}=i+\underbrace{(1-\theta) \frac{\eta_{\mathrm{C}}^{\alpha}}{1-\alpha}}_{\mathrm{RFP}_{\mathrm{C}}} B .
$$


Finally, the demand for specialized capital, labeled $k_{\mathrm{CP}} \equiv k\left(i, \tau^{\mathrm{E}}, \tau^{\mathrm{B}}\right)$, solves

$$
\frac{\pi}{1-\pi}\left[f^{\prime}\left(k_{\mathrm{C}}\right)-\gamma\right]=1+i+\alpha\left[\pi\left(1-\tau^{\mathrm{E}}\right)+(1-\pi) \tau^{\mathrm{B}}\right] \mathrm{RFP}_{\mathrm{C}}+\left[1-(1-\theta) \eta_{\mathrm{C}}^{\alpha}\right] C .
$$

Note that (20) reduces to (9) if $\tau^{\mathrm{E}}=\tau^{\mathrm{B}}=0$, and all money is injected in the CM.

\subsection{Credit policy, welfare, and optimal monetary policy}

Let us first examine how the credit policy affects steady state welfare and the optimal intervention by the monetary authority. Through the credit policy the monetary authority can now influence the old bankers' effort by altering the mix relationship loans-cash holdings. By influencing their effort, the credit policy also affects the RFP and the demand for specialized capital.

The monetary authority chooses $\left(i, \tau^{\mathrm{E}}, \tau^{\mathrm{B}}\right)$ to maximize the ex-ante welfare

$\mathcal{W}\left(i, \tau^{\mathrm{E}}, \tau^{\mathrm{B}}\right)=\pi \gamma+\mu \pi\left[f\left(k_{\mathrm{C}}\right)-\gamma k_{\mathrm{C}}\right]-\mu(1-\pi)\left\{\frac{\eta_{\mathrm{C}}}{1-\pi}+\left(1-\eta_{\mathrm{C}}^{\alpha}\right)(C+\phi \pi B)\right\} k_{\mathrm{C}}$.

We study whether it is optimal to choose an active credit policy, setting a positive $\tau^{\mathrm{E}}$ or $\tau^{\mathrm{B}}$. Precisely, we consider a scenario where, as in the baseline environment, credit policy is inactive and $\tau^{\mathrm{E}}=\tau^{\mathrm{B}}=0$; and examine the effect of a small increase in either $\tau^{\mathrm{E}}$ or $\tau^{\mathrm{B}}$. With respect to $\tau^{\mathrm{E}}$ (the share of liquidity directly injected into failed entrepreneurs), we obtain that, regardless of whether it is optimal or not to follow the Friedman rule, the overall impact on welfare satisfies

$$
\frac{\partial \mathcal{W}(i, 0,0)}{\partial \tau^{\mathrm{E}}}>\frac{\mu}{\theta}\left(\theta-\frac{C+\phi \pi B}{C+\pi B}\right) \frac{\pi B}{C+\pi B} \widehat{\eta} k(\widehat{\eta})
$$

which is positive whenever (13) holds and there is too much effort of bankers compared to the planner's solution ( $\left.\widehat{\eta}>\eta^{\text {planner }}\right)$. Intuitively, a liquidity transfer to failed entrepreneurs reduces the demand for bank loans, attenuating bankers' excessive effort incentive.

With respect to $\tau^{\mathrm{B}}$ (the share of liquidity directly injected into bankers), we obtain that

$$
\frac{\partial \mathcal{W}(\widehat{i}, 0,0)}{\partial \tau^{\mathrm{B}}}=-\frac{\mu}{\theta} \frac{1-\pi}{\pi} \frac{1}{1-\alpha}\left(\theta-\frac{C+\phi \pi B}{C+\pi B}\right) \frac{\pi B}{C+\pi B} \widehat{\eta} k(\widehat{\eta})
$$

which, following (13), is strictly positive if and only if $\widehat{\eta}<\eta^{\text {planner }}$ and bankers' effort is inefficiently low relative to the planner's solution. Intuitively, a liquidity transfer 
to bankers allows the monetary authority to boost their effort towards the planner's solution in (14). ${ }^{15}$ Summarizing, credit policies can improve welfare compared to the baseline environment. However, the optimal target of the credit policy (the banking sector or the entrepreneurial sector) depends on how bankers' effort stands relative to the optimal effort level and, hence, on the tightness of credit relationships.

\subsection{Credit policy and shocks}

Let us next study how the credit policy influences the resilience to shocks. To mimic the credit market interventions implemented in recent years in response to the Great Recession, we consider a scenario where the monetary authority adopts a credit policy that targets a constant relative loan supply $\pi\left(1-\tau^{\mathrm{E}}\right)+(1-\pi) \tau^{\mathrm{B}}$. In particular, in response to a negative shock to $\pi$, the monetary authority reshuffles its liquidity injection from the CM to the decentralized stage (with $\tau^{\mathrm{E}}$ and $\tau^{\mathrm{B}}$ again being the weights of the direct liquidity injections into entrepreneurs and bankers, respectively). Under this policy, the effect on the demand for specialized capital of a drop in $\pi$ becomes

$\frac{\partial k_{\mathrm{C}}}{\partial \pi}=\frac{-(1-\pi)}{\pi f^{\prime \prime}\left(k_{\mathrm{C}}\right)}\{\frac{f^{\prime}\left(k_{\mathrm{C}}\right)-\gamma}{(1-\pi)^{2}}-\underbrace{\alpha\left[1-\frac{(1-\alpha) C}{\alpha \pi B}+\frac{(1-\pi) \tau^{B}}{\pi}-\tau^{\mathrm{E}}\right] \operatorname{RFP}_{\mathrm{C}} \epsilon_{\mathrm{C}}}_{\text {Effect of Credit Relationships with Active Credit Policy }}-\frac{\partial i}{\partial \pi}\}$,

where

$$
\epsilon_{\mathrm{C}} \equiv \frac{\partial \mathrm{RFP}_{\mathrm{C}}}{\partial \pi} \frac{\pi}{\mathrm{RFP}_{\mathrm{C}}}=\alpha \frac{\partial \eta_{\mathrm{C}}}{\partial \pi} \frac{\pi}{\eta_{\mathrm{C}}}=-\frac{\alpha}{1-\alpha} \frac{\pi}{1-\pi} .
$$

Under a credit policy that offsets the impact of a drop in $\pi$ on the real credit supply, we have that $\epsilon_{\mathrm{C}}$ is always negative, so the RFP rises. This occurs because a larger involvement of bankers in the funding of projects leads to a larger effort of bankers and, hence, a higher RFP. Under this policy, credit relationships dampen a negative real shock if and only if the second term on the right-hand side of (21) is positive, i.e.,

$$
\tau^{\mathrm{E}}-\frac{1-\pi}{\pi} \tau^{\mathrm{B}}>1-\frac{1-\alpha}{\alpha} \frac{C}{\pi B}
$$

\footnotetext{
${ }^{15}$ Interestingly, the liquidity transfers to bankers boost bankers' effort without exacerbating entrepreneurs' excessive demand for capital. In fact, in response to the increase in bankers' effort, the RFP rises, leading to a drop in specialized capital demand. That is, the credit policy also complements the role of the nominal interest rate in tapering off the demand for specialized capital.
} 
Intuitively, if the credit policy is biased towards injecting liquidity into bankers $\left(\tau^{\mathrm{E}}\right.$ is low relative to $\tau^{\mathrm{B}}$ ), the increase in the RFP induced by the negative shock amplifies the effects of the shock on specialized capital demand and output. By contrast, if most liquidity injections go to failed entrepreneurs $\left(\tau^{\mathrm{E}}\right.$ is high relative to $\left.\tau^{\mathrm{B}}\right)$, entrepreneurs are able to fund larger projects, despite the increase in the RFP. Thus, the credit policy helps restore a stabilizing role of credit relationships if liquidity is injected directly into firms rather than into bankers.

\section{Conclusion}

The influence of the credit sector on the aggregate economy is the object of an intense debate. The last decades have been characterized by profound structural transformations that have allegedly diluted the strength of credit relationships. This paper has investigated the aggregate effects of credit relationships in a decentralized monetary economy where firms resort to both internal liquidity (cash holdings) and to relationship loans. The economy features a complementarity between lenders' liquidity provision and their effort in acquiring knowledge, information and skills about firms' projects: the larger the share of liquidity needs covered by a lender, the stronger the lender's involvement in the projects of the firm, and the stronger her incentive to acquire knowledge about the projects. We have found that tight credit relationships can be associated with a suboptimally low cost premium of relationship loans. This, in turn, can call for a departure from the Friedman rule. On the other hand, loose credit relationships can be associated with a countercyclical cost premium of relationship loans, reducing the resilience to shocks. Credit policies can enhance the welfare benefits of credit relationships. They can also help restore their stabilizing role as long as they target the entrepreneurial, rather than the lending, sector.

The paper leaves important questions open. A relevant aspect regards the structure of firms' external financing. For example, while in our economy loans of financial institutions constitute the only form of external finance, firms fund a share of their investments through interfirm credit. It is often thought that trade creditors can acquire superior skills at enhancing the collateral value of firms' assets. This can have important implications for the aggregate effects of the credit sector and of credit relationships. We leave the exploration of this and other issues for future research. 


\section{References}

Banca d'Italia, 2003. Bollettino Statistico IV-2003.

Bates, T. W., K. M. Kahle and R. M. Stulz, 2009. Why do U.S. firms hold so much more cash than they used to? Journal of Finance 64, 1985-2021.

Beck, T.H.L., H.A. Degryse, R. de Haas and N. van Horen, 2018. When arm's length is too far: Relationship banking over the credit cycle. Journal of Financial Economics 127, 174-196.

Berger, A. N. and G. F. Udell, 2002. Small business credit availability and relationship lending: The importance of bank organisational structure. Economic Journal, 112, F32-F53.

Berger, A.N., Udell, G.F., 2006. A more complete conceptual framework for SME finance. Journal of Banking and Finance 30, 2945-2968.

Berndt, A. and A. Gupta, 2009. Moral hazard and adverse selection in the originateto-distribute model of bank credit. Journal of Monetary Economics, CarnegieRochester Conference Series on Public Policy 56, 725-743.

Boot, A. W. A. and A. V. Thakor, 2000. Can relationship banking survive competition? Journal of Finance 55, 679-713.

Branch, B., 2002. The costs of bankruptcy: A review. International Review of Financial Analysis 11, 39-57.

Campello, M. E. Giambona, J. R. Graham and C. R. Harvey, 2011. Liquidity management and corporate investment during a financial crisis. Review of Financial Studies 24, 1944-1979.

Cavalcanti, R. and N. Wallace, 1999. A model of private bank-note issue. Review of Economic Dynamics 2, 104-136.

Cerqueiro G., S. Ongena and K. Roszbach, 2016. Collateralization, bank loan rates, and monitoring. Journal of Finance 71, 1295-1322.

Chemmanur, T.J. and P. Fulghieri, 1994. Reputation, renegotiation, and the choice between bank loans and publicly traded debt. Review of Financial Studies 7, 475-506.

Covas, F. and W. J. Den Haan, 2011. The cyclical behavior of debt and equity finance. American Economic Review 101, 877-99.

De Cecco, M. and G. Ferri, 1996. Le banche d'affari in Italia. Il Mulino, Bologna.

Degryse, H., M. Kim and S. Ongena, 2009. Microeconometrics of banking: methods, applications, and results. Oxford University Press, USA. 
Diamond, D. W. and R. G. Rajan, 2000. A theory of bank capital. Journal of Finance $55,2431-2465$.

Diamond, D. W. and R. G. Rajan, 2001a. Liquidity risk, liquidity creation, and financial fragility: A theory of banking. Journal of Political Economy 109, 287-327.

Diamond, D. W. and R. G. Rajan, 2001b. Banks, short-term debt and financial crises: theory, policy implications and applications. Journal of Monetary Economics - Carnegie-Rochester Conference Series on Public Policy 54, 37-71.

Diamond, D. W. and R. G. Rajan, 2008. Money in a theory of banking. American Economic Review 96, 30-53.

ECB, 2014. Report of the Advisory Scientific Committee of the European Systemic Risk Board, n.4, Frankfurt.

Edwards, J. and K. P. Fisher, 1994. Banks, Finance and Investment in Germany. Cambridge University Press, Cambridge.

Eisfeldt, A. and A. Rampini, 2006. Capital reallocation and liquidity. Journal of Monetary Economics 53, 369-399.

Elsas, R., 2005. Empirical determinants of relationship lending. Journal of Financial Intermediation $14,32-57$.

Ferri, G., R. Minetti and P. Murro, 2019. Credit relationships in the great trade collapse. Micro evidence from Europe. Journal of Financial Intermediation 40.

Gavazza, A., 2011. The role of trading frictions in real asset markets. American Economic Review 101. 1106-43.

Gertler, M. and P. Karadi, 2011. A model of unconventional monetary policy. Journal of Monetary Economics 58, 17-34.

Gertler, M. and N. Kiyotaki, 2010. Financial intermediation and credit policy in business cycle analysis. In: B. M. Friedman and M. Woodford, eds., Handbook of Monetary Economics 1, 3, pp. 547-599.

Gu, C., F. Mattesini, C. Monnet and R. Wright, 2013. Banking: A new monetarist approach. Review of Economic Studies 80, 636-662.

Guiso, L. and R. Minetti, 2010. The structure of multiple credit relationships: Evidence from U.S. firms. Journal of Money, Credit and Banking 42, 1037-1071.

Gustafson, M., I. Ivanov and R. R. Meisenzahl, 2017. Bank monitoring: Evidence from syndicated loans. Working paper, Penn State University. 
Habib, M. A. and D. B. Johnsen, 1999. The financing and redeployment of specific assets. Journal of Finance 54, 693-720.

Hachem, K., 2011. Relationship lending and the transmission of monetary policy. Journal of Monetary Economics 58, 590-600.

Hoshi, T., A. Kashyap and D. Sharfstein, 1990. The role of banks in reducing the costs of financial distress in Japan. Journal of Financial Economics 27, 67-88.

Höwer, D., 2016. The role of bank relationships when firms are financially distressed. Journal of Banking \& Finance 65, 59-75.

Jiangli, W., H. Unal and C. Yom, 2008. Relationship lending, accounting disclosure, and credit availability during the Asian financial crisis. Journal of Money, Credit, and Banking 40, 26-55.

IMF, 2006. World Economic Outlook. Financial Systems and Economic Cycles. Washington, D.C.

IMF, 2012. Global Financial Stability Report. Washington, D.C.

Krozner, R. 2015. The future of banks: Will commercial banks remain central to the financial system? Prepared for the Federal Reserve Bank of Atlanta conference "Central Banking in the Shadows: Monetary Policy and Financial Stability Postcrisis".

Lagos, R., G. Rocheteau and R. Wright, 2017. Liquidity: A new monetarist perspective. Journal of Economic Literature 55, 371-440.

Lagos, R. and R. Wright, 2005. A unified framework for monetary theory and policy analysis. Journal of Political Economy 113, 463-484.

Li, Y., A. Saunders and P. Shao, 2015. The monitoring incentive of transactional and relationship lenders: Evidence from the syndicated loan market. Journal of Money, Credit and Banking 47, 701-735.

Lorenzoni, G., 2008. Inefficient credit booms. Review of Economic Studies 75, 809833.

Maksimovic, V. and G. Phillips, 2001. The market for corporate assets: Who engages in mergers and asset sales and are there efficiency gains? Journal of Finance 56, 20192065.

Norden, L. and M. Weber, 2010. Credit line usage, checking account activity, and default risk of bank borrowers. Review of Financial Studies 23, 3665-3699.

Nosal, E. and G. Rocheteau, 2011. Money, Payments, and Liquidity. MIT Press, Cambridge. 
Ongena, S., G. Tümer-Alkan and N. Westernhagen, 2012. Creditor concentration: An empirical investigation. European Economic Review 56, 830-847.

Pinkowitz, L., 2001. Bank power and cash holdings: Evidence from Japan. Review of Financial Studies 14, 1059-1082.

Pulvino, T., 1998. Do asset fire sales exist? An empirical investigation of commercial aircraft transactions. Journal of Finance 53, 939-978.

Ramey, V. and M. Shapiro, 2001. Displaced capital: A study of aerospace plant closings. Journal of Political Economy 109, 958-992.

Rocheteau, G., R. Wong and C. Zhang, 2018. Lending relationships and optimal monetary policy. Manuscript, University of California, Irvine.

Rocheteau, G., R. Wright and C. Zhang, 2018. Corporate finance and monetary policy. American Economic Review 108, 1147-86.

Sette, E. and G. Gobbi, 2015. Relationship lending during a financial crisis. Journal of the European Economic Association 13, 453-481.

Sheard, P., 1994. Main banks and the governance of financial distress. In: The Japanese Main Banking System: Its Relevance for Developing and Transforming Economies, M. Aoki and H. Patrick, eds. Oxford University Press, Oxford.

Shimizu K., 2012. Bankruptcies of small firms and lending relationship. Journal of Banking and Finance 36, 857-870.

Shleifer, A. and R. W. Vishny, 1992. Liquidation values and debt capacity: A market equilibrium approach. Journal of Finance 47, 1343-1366.

Sufi, A., 2007. Information asymmetry and financing arrangements: Evidence from syndicated loans. Journal of Finance 62, 629-668.

Wang, Y. and H. Zia, 2014. Do lenders still monitor when they can securitize loans? Review of Financial Studies 27, 2354-2391.

\section{Appendix}

In what follows, we make sure that it is always optimal to restructure a failed specialized project. If the young entrepreneur receives the opportunity to implement the specialized project but he anticipates that he will not restructure in case the project fails, his expected payoff if he chooses capital $k$ and money holdings $m$ is

$$
-\phi_{k} k-\phi_{m_{-1}} m+\beta \pi f(k)+\beta \pi \phi_{k} k+\beta \phi_{m}\left(1+i_{d}\right) m \text {. }
$$


This payoff is similar to the expected payoff under a general project, the only differences are that $\gamma k$ is replaced with $f(k)$ and the capital can only be sold in the following $\mathrm{CM}$ if the project succeeds. As a result, the same reasoning used in the case of general projects implies that it is weakly optimal not to demand any money. The optimal choice of specialized capital then solves

$$
f^{\prime}(\widetilde{k})=\frac{1-\beta \pi}{1-\beta} \gamma
$$

Consider now a hypothetical scenario where the young entrepreneur chooses $\widetilde{k}$ and also chooses not to use the knowledge acquisition services of the old banker. Instead, he brings enough money to restructure the capital in case it fails. This sets a lower bound on the expected payoff under restructuring, given by

$$
-\phi_{k} \widetilde{k}-\phi_{m_{-1}} \widetilde{m}+\beta \pi f(\widetilde{k})-\beta(1-\pi) C+\beta \phi_{k} \widetilde{k}
$$

where $\phi_{m} \widetilde{m}=\widetilde{k}$. Under this hypothetical scenario, it is optimal to restructure if and only if

$$
-\phi_{k} \widetilde{k}-\beta(1+i) \widetilde{k}+\beta \pi f(\widetilde{k})-\beta(1-\pi) C+\beta \phi_{k} \widetilde{k} \geq-\phi_{k} \widetilde{k}+\beta \pi f(\widetilde{k})+\beta \pi \phi_{k} \widetilde{k},
$$

which can be rewritten as

$$
1+i \leq(1-\pi)\left(\frac{\beta}{1-\beta} \pi \gamma-\frac{C}{\widetilde{k}}\right) .
$$

We assume that this inequality holds, which is always true if $\beta$ is high enough. 

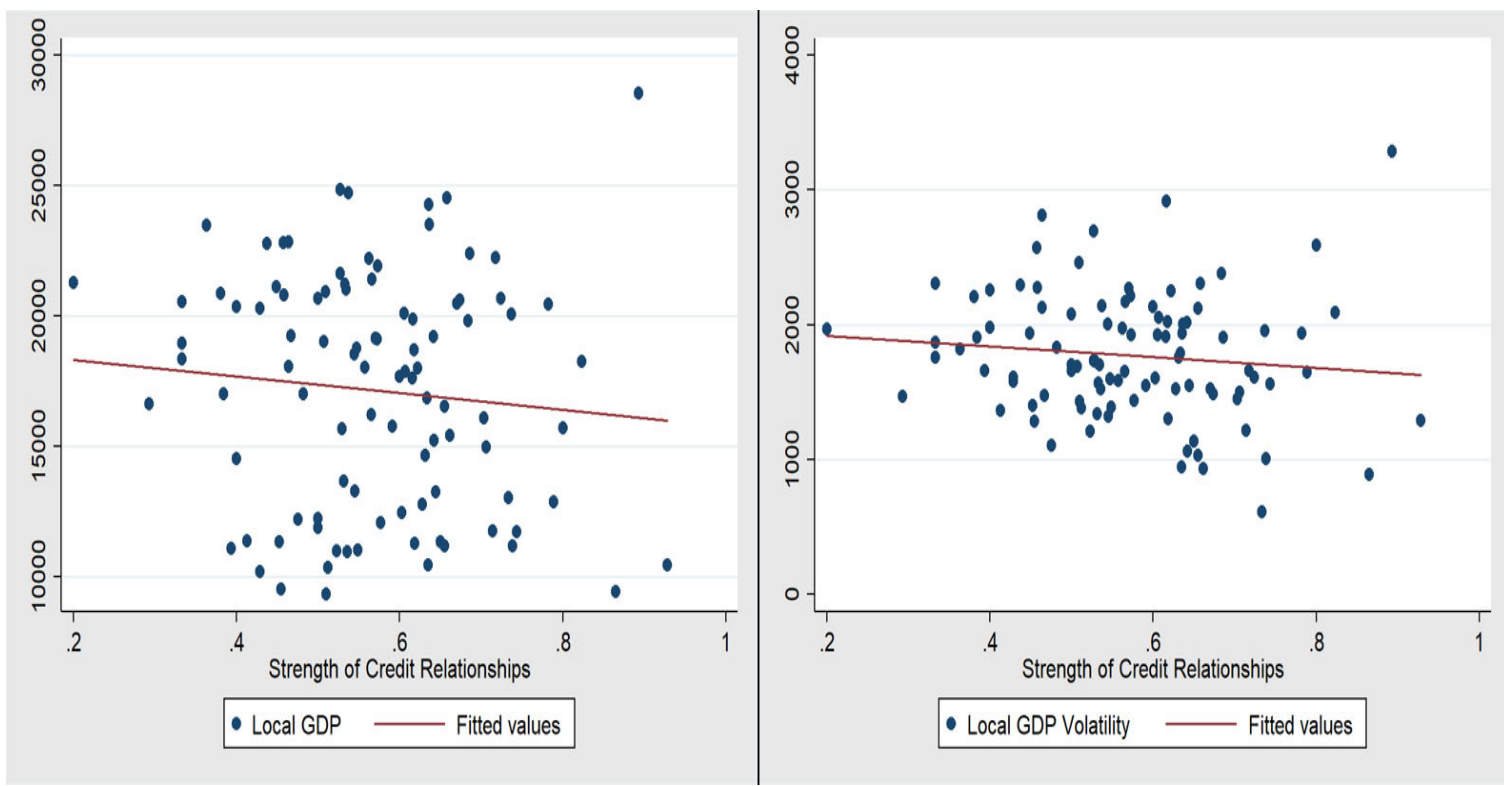

Figure 1: Credit Relationships, Output Levels and Volatility.

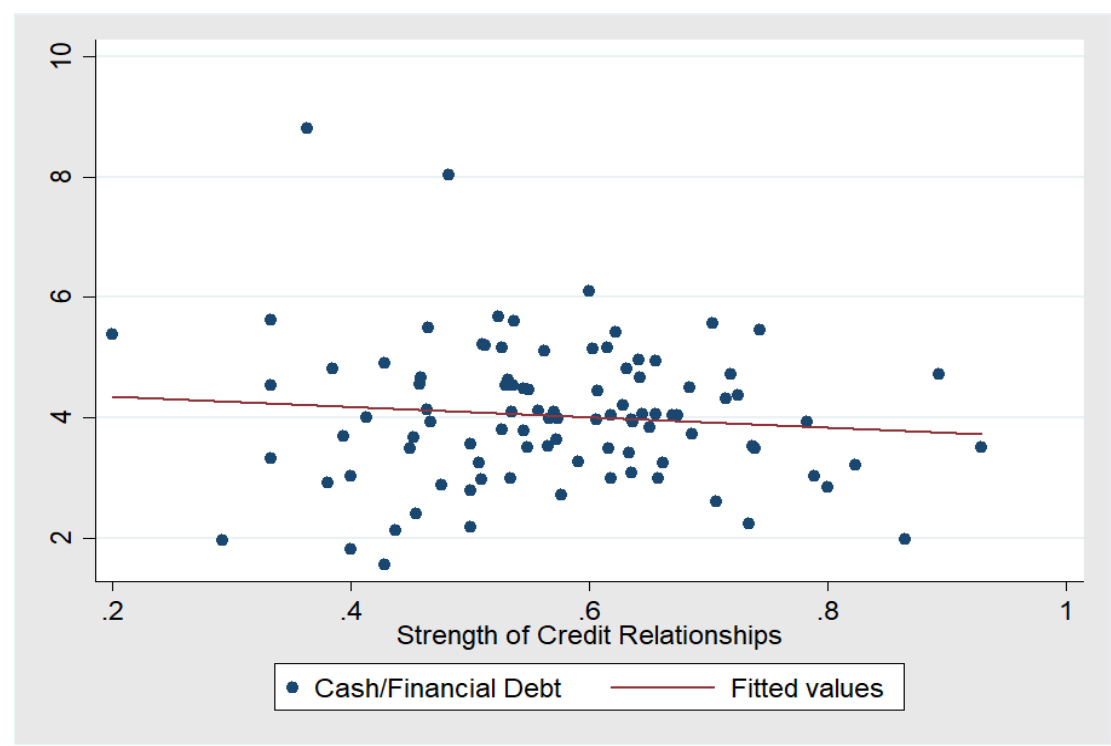

Figure 2: Credit Relationships and Firms' Cash Holdings. 


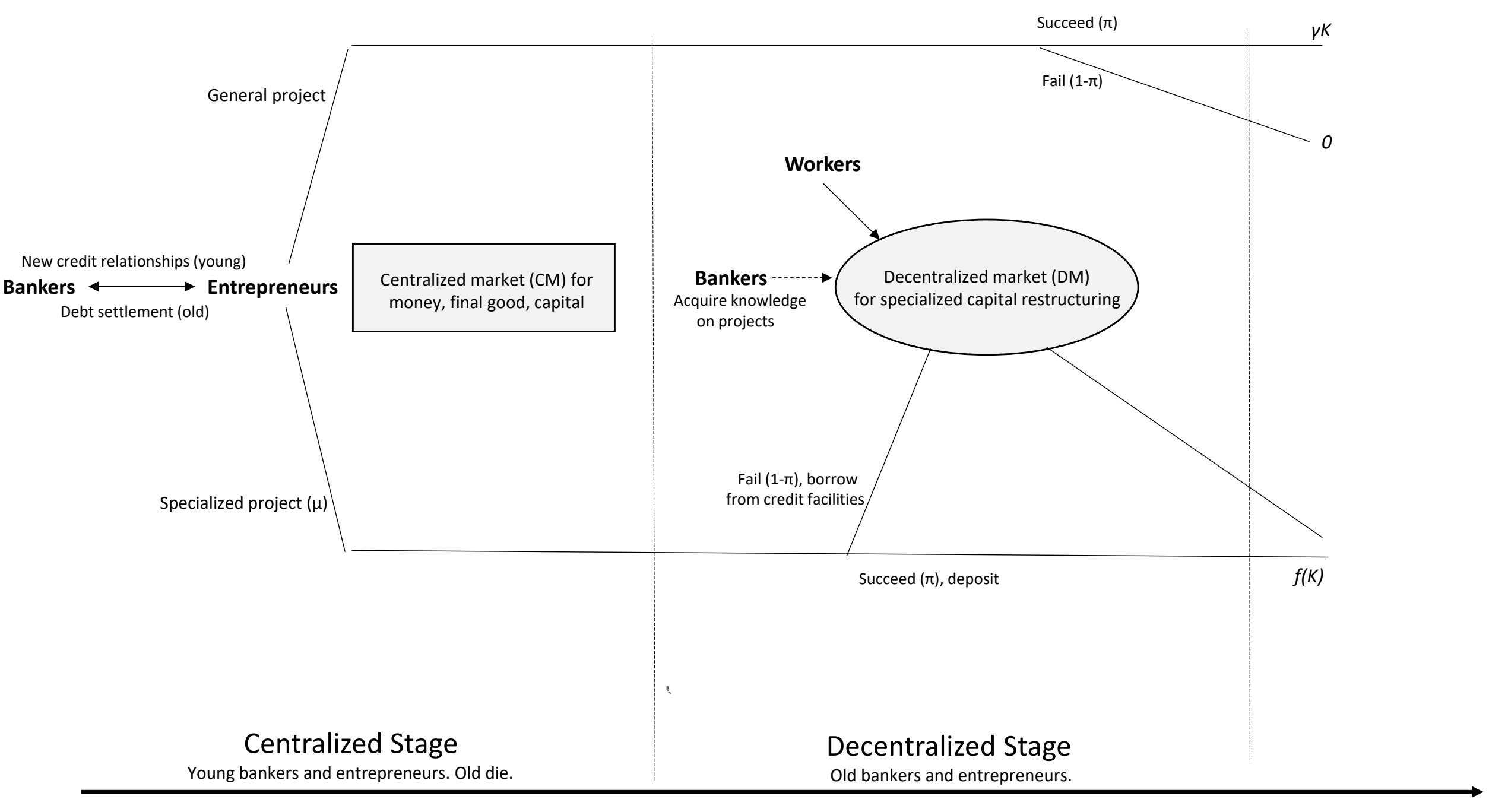

Figure 3: Timeline. 


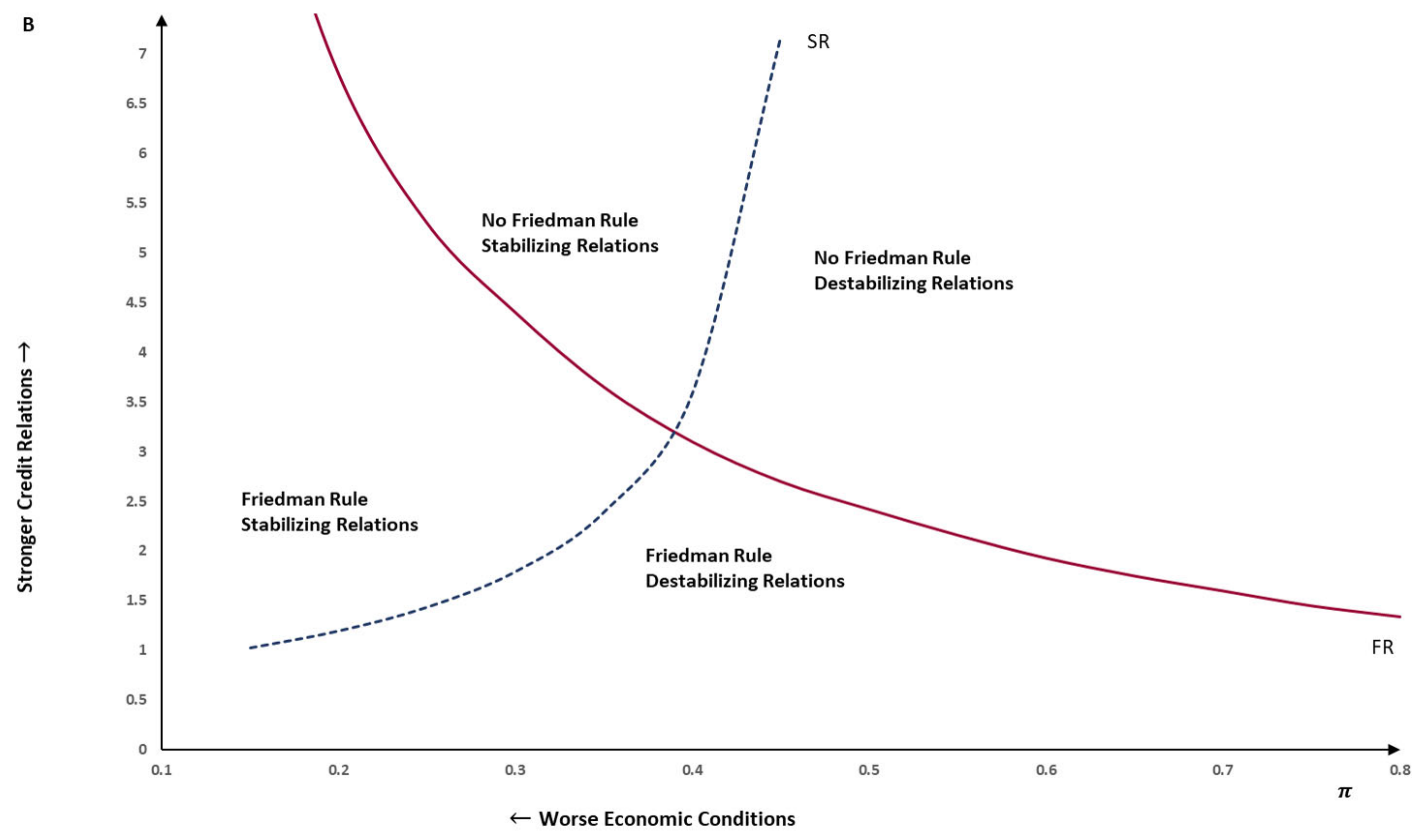

Figure 4: Effects of Credit Relationships.
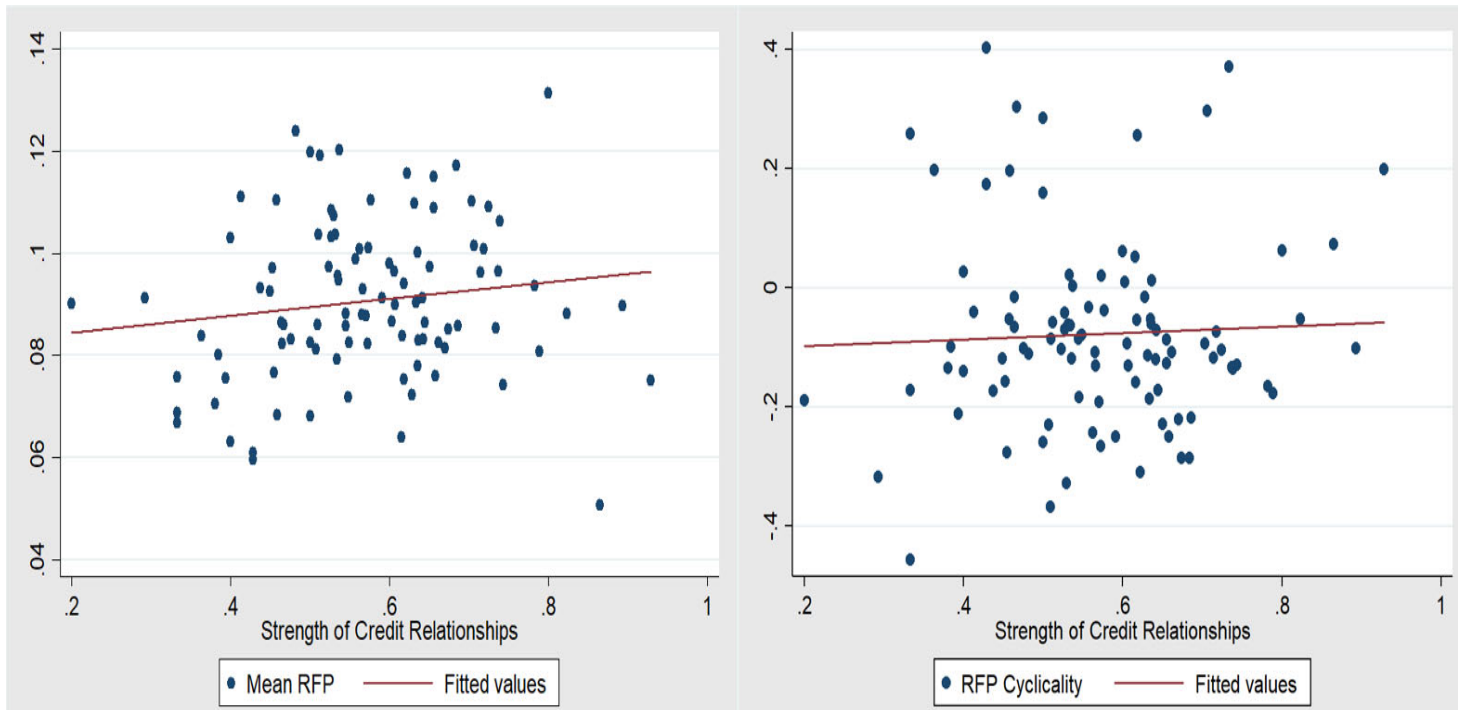

Figure 5: Credit Relationships, RFP Levels, and RFP Cyclicality. 